\title{
Root System Distribution of Sweet Cherry Trees Grafted on Vigorous Rootstock in Molic Eutricambosoil in Northern Transylvania
}

\author{
Zsolt JAKAB-ILYEFALVI*
}

Fruit Research and Development Station Bistrița, Romania

*Corresponding author: Zsolt JAKAB-ILYEFALVI e-mail: zsolt.jakab@yahoo.com

RESEARCH ARTICLE

\begin{abstract}
The type of the root system development of different species and cultivars gives valuable information for choosing of proper rootstock/scion combinations in different soils and soil horizons, the establishment of active rhizosphere where the input nutrition can give maximum results. Researches showed that cherry grafted on a vigorous rootstock in molic eutricambosoil develops a root system which is mainly horizontally spread $\left(88-90^{\circ}\right)$, in some rare cases with angles of $45^{\circ}$, with 5-7 strong $\mathrm{V}$ order roots ( $>80 \mathrm{~mm}$ ) which provides good anchorage for trees. To the periphery the roots reached up to $6.5-8.5 \mathrm{~m}$ in the old trees and $3.5 \mathrm{~m}$ in the young trees. The depth of the root system achieved 2.0-2.5 $\mathrm{m}$ in the old trees and 1.0-1.5 $\mathrm{m}$ in the young trees. The highest quantity of roots were observed between 18-60 cm depth in both young and old trees.
\end{abstract}

Keywords: eutricambosoil; main order roots; rhizosphere.

Received: 15 September 2020 Accepted: 01 February 2021 Published: 14 May 2021

DOI:

15835/buasvmen-hort:2020.0046

\section{INTRODUCTION}

The root system and his multilevel functions in the life of a fruit tree is essential in the nutrition, development, anchorage and the whole sustaining of the crown system, thus the fruit yield. The knowledge of the spatial architecture of the root system, influenced by specific environmental conditions makes possible to apply correct fruit growing technologies. The knowledge of the root system development of different rootstocks gives valuable information in the choosing process of proper rootstock/scion combinations for different soils and soil horizons, for the establishment of active rhizosphere where the input nutrition can give maximum results (Bohm, 1979; Atkinson, 1980; Voiculescu, 1983; Wertheim, 1998; Grzyb et al., 1998; Sitarek et al., 1999; Moreno et al., 2001; Webster, 2004; Whiting et al., 2005; Black et al., 2010; Bielicki et al., 2010; Cantin et al., 2010; Lanauskas et al., 2012; Milosevic et al., 2014; Robinson et al., 2014; Aglar et al., 2016).

The aim of the studies was to assess biometrical measurements of several indicators of root system development in some cherry cultivars grafted on vigorous rootstock in molic eutricambosoil which is frequent in Northern Transylvania.

\section{MATERIALS AND METHODS}

Researches were carried out in a cherry orchard planted with 'Kordia' and 'Hedelfingen' cultivars grafted on a strong growing wild cherry rootstock, in molic License 
eutricambosoil. The experimental orchard was planted in 1980, with a density of 277 trees/ha, planting distance of $6 \times 6 \mathrm{~m}$ with open vase training system. The orchard rows were left uncultivated and covered with natural grass, which was mowed several times during the season. Both the aboveground part of the tree regarding height of tree, diameter of crown and thickness of trunk (trunk cross section area), and the underground part of the actual root system were measured. At the root system the following indicators were measured: the diameter of the rhizosphere of different cultivar/rootstock combination, the individual analysis of root categories, the ramification angle, the depth of soil where the greatest amount of roots were. The excavation method described by Bohm (1979) was used for dislocation of soil in concentric rings by a caterpillar, being careful not to harm the principal order roots, starting from the periphery and ending near the tree trunk, both in depth and in surface. The trees were measured with a digital calliper Matheus CR89 model and with a measuring tape, recording numerical data.

\section{RESULTS AND DISCUSSIONS}

After systematic researches of the root system, data showed that sweet cherry cultivars grafted on a strong growing wild cherry rootstock in molic eutricambosoil developed a root system which is mainly horizontally spread (88$90^{\circ}$ ), in some rare cases with angles of $45^{\circ}$ (Table 1 ).

The highest quantity of roots was observed between $18-60 \mathrm{~cm}$ depth, both in young and old trees. Regarding the category of different roots, one can observe that in heavy clay soils, roots tend to grow horizontally, developing strong "V" order roots $(>80 \mathrm{~mm})$ which helps a good anchorage of trees (Table 1$)$. To the periphery, the roots extended till 6.5-8.5 $\mathrm{m}$ in the old trees ('Kordia', 'Hedelfingen') and $3.5 \mathrm{~m}$ in the young trees. 5).

The depth of the root system achieved 2.2-2.5 $\mathrm{m}$ in the old trees and 1.3-1.5 $\mathrm{m}$ in the young trees (Tables 2, 3,

Table 1. Categories of roots established in the process of root dislocation

\begin{tabular}{ccc}
\hline Category & $\begin{array}{c}\text { Root diameter } \\
(\mathbf{m m})\end{array}$ & $\begin{array}{c}\text { Ramification angle } \\
\left({ }^{\circ}\right)\end{array}$ \\
\hline I & $0-4$ & $30-40$ \\
\hline II & $4-10$ & $45-50$ \\
\hline III & $10-30$ & 65 \\
\hline IV & $30-80$ & $80-85$ \\
\hline V & $>80$ & $88-90$ \\
\hline
\end{tabular}

There can be observed that the penetration of the roots in depth is connected with their branching and the soil type. When the geo-trophic angle is little, the roots can penetrate deeper layers of soils but if the soil type is compact and heavy, the tendency is that roots will be situated more on the surface of the soil.

Generally, the number of roots decreased from the trunk rhizosphere to the periphery. The tiny roots grew in the maximum of 1-3 m zone, immediately in the circumference zone of the crown. In the young, 12 years of age 'Kordia' trees, roots together with the rootstock base represented $22.38 \%$ and the aboveground part represented $67.13 \%$ of the tree weight (Table 2).

The depth of roots in the younger trees penetrated the soil layer of $1.5 \mathrm{~m}$ in a diameter of $3.2 \mathrm{~m}$. Both the young 'Kordia' and 'Hedelfingen' trees grafted on wild cherry, had close values regarding the diameter of crown and the diameter of rhizosphere (Table 2).

Data analysis regarding 'Kordia' cultivar grafted on wild cherry with 39 years of age showed that the diameter of rhizosphere (Table 3) was almost the double of the rhizosphere size of younger 'Kordia' trees (Table 2). Roots with different categories however in weight were much greater than the younger trees, the share of $23.75 \%$ was almost the same as for younger ones. Aboveground part is slightly smaller in amount and the root system was much larger than in younger trees. 
Table 2. Biometrical data analysis of young 'Kordia' and 'Hedelfingen' trees, grafted on wild cherry, age 12 years (Fruit Research and Development Station Bistrita)

\begin{tabular}{|c|c|c|c|c|c|c|c|c|c|}
\hline \multirow[b]{2}{*}{$\begin{array}{l}\text { Parts of the } \\
\text { tree }\end{array}$} & \multicolumn{6}{|c|}{ Weight } & \multirow[b]{2}{*}{ Characters } & \multicolumn{2}{|c|}{ Dimensions (m) } \\
\hline & $\begin{array}{c}\text { Kordia } \\
(\mathrm{kg})\end{array}$ & $\begin{array}{c}\text { Hedel- } \\
\text { fingen } \\
(\mathrm{kg})\end{array}$ & $\begin{array}{c}\text { Kordia } \\
(\%)\end{array}$ & $\begin{array}{l}\text { Hedel- } \\
\text { fingen } \\
(\%)\end{array}$ & $\begin{array}{c}\text { Kordia } \\
(\%)\end{array}$ & $\begin{array}{c}\text { Hedel- } \\
\text { fingen } \\
(\%)\end{array}$ & & Kordia & $\begin{array}{l}\text { Hedel- } \\
\text { fingen }\end{array}$ \\
\hline $\begin{array}{c}\text { Roots of } \\
\text { different } \\
\text { categories }\end{array}$ & 6.8 & 7.2 & 9.51 & 10.90 & 22.38 & 24.36 & Crown diameter & 3.20 & 3.5 \\
\hline Rootstock base & 9.2 & 8.9 & 12.87 & 13.46 & & & Tree height & 5.50 & 5.20 \\
\hline Trunk & 7.5 & 6.8 & 10.49 & 10.28 & 10.49 & 10.28 & Trunk height & 0.80 & 0.82 \\
\hline Main branches & 35.5 & 30.2 & 49.65 & 45.68 & 67.13 & 65.36 & Trunk diameter & 0.15 & 0.13 \\
\hline $\begin{array}{c}\text { Fruiting } \\
\text { branches }\end{array}$ & 12.5 & 13.0 & 17.48 & 19.68 & & & $\begin{array}{c}\text { Rhizosphere } \\
\text { depth }\end{array}$ & 1.50 & 1.30 \\
\hline TOTAL & 71.5 & 66.1 & 100.00 & 100.00 & & 100.00 & $\begin{array}{c}\text { Rhizosphere } \\
\text { diameter }\end{array}$ & 3.50 & 3.20 \\
\hline
\end{tabular}

Table 3. Biometrical data analysis of old 'Kordia' trees grafted on seedling cherry, age 39 years (Fruit Research and Development Station Bistrita)

\begin{tabular}{|c|c|c|c|c|c|}
\hline \multirow{2}{*}{ Parts of the tree } & \multicolumn{3}{|c|}{ Weight } & \multirow{2}{*}{ Characters } & \multirow{2}{*}{$\begin{array}{c}\text { Dimensions } \\
(\mathrm{m})\end{array}$} \\
\hline & kg & $\%$ & $\%$ & & \\
\hline $\begin{array}{l}\text { Roots with different } \\
\text { categories }\end{array}$ & 42 & 11.73 & 23.75 & Crown diameter & 6.50 \\
\hline Rootstock base & 43 & 12.02 & & Tree height & 7.50 \\
\hline Trunk & 58 & 16.21 & 16.2 & Trunk height & 2.00 \\
\hline Main branches & 120 & 33.51 & 60.04 & Trunk diameter & 0.44 \\
\hline Fruiting branches & 95 & 26.53 & & Rhizosphere depth & 2.50 \\
\hline TOTAL & 358 & 100.00 & 100.00 & Rhizosphere diameter & 8.50 \\
\hline
\end{tabular}

Research results regarding root repartition showed that in younger, 12 years old 'Kordia' trees, there are 4 greater dimension roots of III order and several II order roots which sustain the weight of the tree and several thin I category roots (Table 4). Higher order roots (IV and V) will develop later in time.

Table 4. Data analysis of root repartition in eutricambosoil of 'Kordia' tree grafted on wild cherry, 12 and 39 years old

\begin{tabular}{|c|c|c|c|c|c|}
\hline $\begin{array}{c}\text { Age of } \\
\text { tree }\end{array}$ & $\begin{array}{l}\text { I categ roots. } \\
\text { (0-4 mm diam) } \\
\text { (pieces) }\end{array}$ & $\begin{array}{c}\text { II categ. roots } \\
\text { (4-10 mm } \\
\text { diam.) } \\
\text { (pieces) }\end{array}$ & $\begin{array}{c}\text { III categ. roots } \\
(10-30 \mathrm{~mm} \\
\text { diam) } \\
\text { (pieces) }\end{array}$ & $\begin{array}{c}\text { IV categ. roots } \\
(30-80 \mathrm{~mm} \\
\text { diam) } \\
\text { (pieces) }\end{array}$ & $\begin{array}{c}\text { V categ. roots } \\
\text { (>80 mm } \\
\text { diam.) } \\
\text { (pieces) }\end{array}$ \\
\hline 12 & 32 & 27 & 4 & - & - \\
\hline 39 & 75 & 52 & 7 & 12 & 7 \\
\hline
\end{tabular}

At the other hand in 39 years old 'Kordia' trees, grafted on wild cherry (Table 4) there were 5-7 large roots of V category, some of them were $154 \mathrm{~mm}$ in diameter, which sustain the main weight of the tree, arranged horizontally. There were 10-12 roots of IV category and 5-7 roots of III category, which are also horizontally distributed in the soil.

At 'Hedelfingen' cultivar in younger trees, root distribution was similar to that of 'Kordia'. The roots with different categories represented $24.36 \%$ and aboveground part represented $65.36 \%$ (Table 2). Meanwhile the diameter of crown and the diameter of rhizosphere were almost the same. It seems that in the first years of the tree, both the aboveground part and the root system are developed at the same rate and spatial distribution. In older 'Hedelfingen' trees, root system was $19.82 \%$, which is much less than in 'Kordia' cultivar and the aboveground part (main branches and fruiting branches) represented $65,74 \%$ (Table 5). The diameter of rhizosphere was $7.4 \mathrm{~m}$ and the diameter of the crown $6.2 \mathrm{~m}$, which shows that there is a balance between them.

Research results regarding roots repartition in the soil at young 'Hedelfingen' trees, showed that the sustaining of the tree is based on III category roots $(25-30 \mathrm{~mm}$ in diameter) and several roots of II order (Table 6). In old 'Hedelfingen' trees the main roots were also represented by IV and V category, distributed with an angle of 88-89', with several branching. The largest amount was represented by I and II order roots (Table 6). 
Table 5. Biometrical data analysis of old 'Hedelfingen' trees grafted on wild cherry, age 39 years (Fruit Research and Development Station Bistrita)

\begin{tabular}{|c|c|c|c|c|c|}
\hline \multirow{2}{*}{ Parts of the tree } & \multicolumn{3}{|c|}{ Weight } & \multirow{2}{*}{ Characters } & \multirow{2}{*}{$\begin{array}{c}\text { Dimensions } \\
\text { (m) }\end{array}$} \\
\hline & kg & $\%$ & $\%$ & & \\
\hline $\begin{array}{l}\text { Roots with different } \\
\text { categories }\end{array}$ & 38 & 10.76 & 19.82 & Crown diameter & 6.20 \\
\hline Rootstock base & 32 & 9.06 & & Tree height & 6.60 \\
\hline Trunk & 51 & 14.44 & 14.44 & Trunk height & 2.00 \\
\hline Main branches & 130 & 36.85 & 65.74 & Trunk diameter & 0.42 \\
\hline Fruiting branches & 102 & 28.89 & & Rhizosphere depth & 2.20 \\
\hline TOTAL & 353 & 100.00 & 100.00 & Rhizosphere diameter & 7.40 \\
\hline
\end{tabular}

Table 6. Data analysis of roots repartition in eutricambosoil of young 'Hedelfingen' tree grafted on wild cherry - age 12 and 39 years old

\begin{tabular}{|c|c|c|c|c|c|c|}
\hline $\begin{array}{l}\text { Age } \\
\text { of } \\
\text { tree }\end{array}$ & $\begin{array}{l}\text { Diameter } \\
\text { of root } \\
\text { system } \\
\text { area (m) } \\
\end{array}$ & $\begin{array}{c}\text { I categ roots. } \\
(0-4 \mathrm{~mm} \\
\text { diam) } \\
\text { (pieces) }\end{array}$ & $\begin{array}{c}\text { II categ. roots } \\
\text { (4-10 mm } \\
\text { diam.) } \\
\text { (pieces) }\end{array}$ & $\begin{array}{c}\text { III categ. roots } \\
(10-30 \mathrm{~mm} \\
\text { diam) } \\
\text { (pieces) }\end{array}$ & $\begin{array}{c}\text { IV categ. roots } \\
(30-80 \mathrm{~mm} \\
\text { diam) } \\
\text { (pieces) }\end{array}$ & $\begin{array}{c}\text { V categ. roots } \\
\text { (>80 mm } \\
\text { diam.) } \\
\text { (pieces) }\end{array}$ \\
\hline 12 & 2.9 & 27 & 25 & 5 & - & - \\
\hline 39 & 6.8 & 68 & 58 & 6 & 13 & 7 \\
\hline
\end{tabular}

In molic eutricambosoil, the root system of greatest category (V) had a predominantly horizontal position $\left(88-90^{\circ}\right)$ while at the lower category roots (II-III) they have a sharper angle penetrating the soil in $45-65^{\circ}$. It seems that in this type of soil both in younger and older trees the roots tend to grow horizontally using the fertile horizon of the soil.

Research results shown in Table 7 denote that there are no statistical differences between the two cultivars at the same age. The existing differences are very small, the root system is spread up to $8.5 \mathrm{~m}$ in diameter and 2.2-2.5 $\mathrm{m}$ in depth in the old 'Kordia' and 'Hedelfingen' trees.

Table 7. Biometrical data comparison of 'Kordia' and 'Hedelfingen' sweet cherry cultivars- 39 age trees

\begin{tabular}{|c|c|c|c|c|}
\hline \multirow{2}{*}{ Parts of the tree } & \multicolumn{2}{|c|}{ Weight } & \multirow{2}{*}{ Characters } & \multirow{2}{*}{$\begin{array}{l}\text { Dimensions } \\
\text { (m) }\end{array}$} \\
\hline & kg & $\%$ & & \\
\hline Roots with different categories-Kordia & 42 & $11.73^{\mathrm{a}}$ & Diameter of crown-Kordia & $6.50^{\mathrm{a}}$ \\
\hline Roots with different categ.-Hedelfingen & 38 & $10.76^{\mathrm{a}}$ & Diameter of crown-Hedelfingen & $6.20^{\mathrm{a}}$ \\
\hline Rootstock base-Kordia & 43 & $12.02^{\mathrm{a}}$ & Height of tree- Kordia & $7.50^{\mathrm{a}}$ \\
\hline Rootstock base-Hedelfingen & 32 & $9.06^{\mathrm{a}}$ & Height of tree- Hedelfingen & $6.60^{\mathrm{a}}$ \\
\hline Trunk-Kordia & 58 & $16.21^{\mathrm{a}}$ & Height of trunk-Kordia & $2.00^{\mathrm{a}}$ \\
\hline Trunk- Hedelfingen & 51 & $14.44^{\mathrm{a}}$ & Height of trunk-Hedelfingen & $2.00^{\mathrm{a}}$ \\
\hline Main branches-Kordia & 120 & $33.51^{\mathrm{a}}$ & Diameter of trunk-Kordia & $0.44^{\mathrm{a}}$ \\
\hline Main branches-Hedelfingen & 130 & $36.85^{\mathrm{a}}$ & Diameter of trunk-Hedelfingen & $0.42^{\mathrm{a}}$ \\
\hline Fruiting branches-Kordia & 95 & $26.53^{\mathrm{a}}$ & Depth of rhizosphere-Kordia & $2.50^{\mathrm{a}}$ \\
\hline Fruiting branches-Hedelfingen & 102 & $28.89^{a}$ & Depth of rhizosphere -Hedelfingen & $2.20^{\mathrm{a}}$ \\
\hline TOTAL-Kordia & 358 & $100.00^{\mathrm{a}}$ & Diameter of rhizosphere-Kordia & $8.50^{\mathrm{a}}$ \\
\hline TOTAL-Hedelfingen & 353 & $100.00^{\mathrm{a}}$ & Diameter of rhizosphere-Hedelfingen & $7.40^{\mathrm{a}}$ \\
\hline
\end{tabular}

Note: Results followed by the same letters in the columns do not differ significantly (Duncan's test, $\mathrm{p}<0.05$ ).

Several researchers reported relationships between root system and soil properties and agreed, that are direct relationships between rootstock, soil properties and root distribution (Black et al., 2010; Robinson et al., 2014; Aglar, 2016; Ruiz-Sanches, 2005). Our research results are in agreement with other researchers work, according to Paltineanu et al. (2016) cherry roots at generative rootstocks are growing horizontally and occupy the entire root space between the studied trees. The fine roots category had the highest number of roots zoned mostly at the surface, near the rootstock base and trunk, showing the great vigor of this rootstock. Paltineanu et al. (2016) confirms that root density slightly decreased with distance from the trunk. They also agree, that large roots (> 5 mm in diameter) were found deeper in the soil, at least about $1.5 \mathrm{~m}$ depth. The pattern of the horizontal fine root system at wild cherry and the root distribution suggests, that the trees are spreading their roots in the upper zone of the fertile soil in order to efficiently use the maximum nutrition components of the soil. 


\section{CONCLUSIONS}

Researches showed that the 'Kordia' and 'Hedelfingen' cherry cultivars grafted on wild cherry rootstock, growing in eutricambosoils, after 39 years develop mainly horizontal root system. Anchorage of cherry trees were very good, they developed strong main order roots which allowed to sustain the tree mechanically and physiologically and to be supplied with water and mineral elements from the soil. Cultivars grafted on wild cherry have a long life span, more than 40 years and in soils with medium clay content develop a good root system and grow successfully.

Author Contributions: Researches were carried out by the main author.

Funding Source: This research was funded by Fruit Research and Development Station Bistrita.

Acknowledgments: I thank the technicians and workers for the help in the excavation of cherry root systems, for the classification and measurements of different rootstock categories.

Conflicts of Interest: The authors declare that they do not have any conflict of interest.

\section{REFERENCES}

1. Atkinson D (1980). The distribution and effectiveness of the roots of tree crops, Hort. Rev. 2:424-490.

2. Aglar E, Yildiz K, Long LE (2016). The effect of rootstocks and training system on the early performance of '009

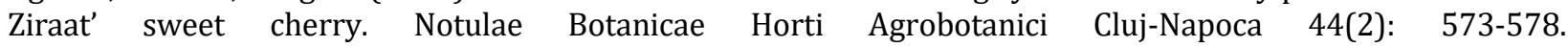
https://doi.org/10.15835/nbha44210401.

3. Bohm W (1979). Methods of studying root systems. Springer-Verlag, Berlin. 188 pp.

4. Black BL, Drost D, Lindstrom T, Reeve J, Gunnell JD, Rheinghard GL (2010). A comparison of root distribution patterns among Prunus rootstocks, J. American Pomological Society 64(1): 52-62.

5. Bielicki P, Rozpara E (2010). Growth and yield of 'Kordia' sweet cherry trees with various rootstock and interstem combinations, Journal of Fruit and Ornamental Plant Research 18(1): 45-50.

6. Cantin C, Pinochet JP, Gogorcena Y, Moreno MA (2010). Growth yield and fruit quality of Van and Stark Hardy Giant sweet cherry cultivars as influenced by grafting on different rootstocks. Sciencia Hort.,123: 329-335.

7. Gryzyb ZS, Sitarek M, Omiecinska B (1998). Growth and fruiting of fiwe sweet cherry cultivars on dwarfing and vigorous rootstocks. Acta Hortic. 468: 333-338.

8. Lanauskas J, Uselis N, Kviklys D, Kvikliene N, Buskiene L (2012). Rootstock effect on the performance of sweet cherry cv. Lapins Hort. Sci. 39: 55-60.

9. Milosevic T, Milosevic N, Milivojevic J, Glisic I, Nikolic R (2014). Experience with Mazzard and Colt sweet cherry rootstocks in Serbia which are used for high density planting system under heavy and acidic conditions. Sci.Hort.176: 261-270.

10. Moreno MA, Adrada R, Aparicio J, Betran JA, (2001). Peformance of Sunburst cherry grafted on different rootstocks, J. Hortic. Sci. Biotechnol., 76: 167-173.

11. Paltineanu C, Septar L, Gavat C Chitu E, Oprita A, Moale C, Lamureanu G, Vrinceanu A (2016). Root density of cherry trees grafted on prunus mahaleb in a semi-arid region. Int. Agrophys., 30: 339-348. doi:10.1515/intag-2016-0001

12. Robinson TL, Hoying SA (2014). Training System and Rootstock Affect Yield, Fruit Size, Fruit Quality and Crop Value of Sweet Cherry, Acta Hort. 1020: 453-462.

13. Ruiz Sanches MC, Plana V, Ortuno MF, Tapia LM, Abrisqueta JM (2005). Spatial root distribution of apricot trees in different soil tillage practices. Plant Soil, 272(1): 211-221.

14. Sitarek M, Gryzyb ZS, Czynczyk A, Omiecinska B (1999). Growth and fruiting of sweet cherry trees grafted on various rootstocks or treated with Cultar. Journal of Fruit and Ornamental Plant Research VII (1): 11-17.

15. Voiculescu N, Teaci D, Popescu I, Puiu S, Amzar G (1983). Parametric expression of the ecopedological influence on the trunk thickness in fruit tree species - I, Soil science no. 2.

16. Voiculescu N, Popescu I, Teaci D, Puiu S (1983). Parametric expression of the ecopedological influence on the trunk thickness in fruit tree species - II, Soil science no. 3.

17. Webster AD, (2004). Vigor mechanisms in dwarfing rootstocks for temperate fruit trees. Acta Horticulture. 658 : 29-41.

18. Wertheim SJ (1998). Rootstock guide: apple pear, cherry, European plum. Fruit Research Station, Wilhelminadorp Bull., The Nederlands.

19. Whiting MD, Lang G, Ophardt D (2005). Rootstock and training system affect sweet cherry growth, yield and fruit quality. Hort. Sci. 40(3): 582-586. 